\title{
THE ESSENCE OF STRATEGIC MANAGEMENT AND ANALYSIS OF MODERN MANAGEMENT APPROACHES
}

\author{
Muzaffar Abdurakhimov \\ A doctoral candidate at the Academy of Public Administration under \\ the President of the Republic of Uzbekistan \\ Crossref \\ http://dx.doi.org/10.26739/2433-202x \\ c \\ Issue DOI http:/ /dx.doi.org/10.26739/2433-202x-2017-12-12 \\ Article DOI http://dx.doi.org/10.26739/2433-202x-2017-12-12-6
}

\section{Abstract}

This article explores the nature of strategic management and the neediness for organizations. It also analyzed the need for new modern management approaches and their uses. Based on the results of the research were developed conclusions and were made recommendations.

Keywords: strategy, strategic planning, strategic management, public administration, new public management, good governance.

In 1960-1970 years, the managers began to use strategic planning in their production areas [1. p-11]. From the 1980s, managers in advanced western firms have moved to strategic management strategies $\left[{ }^{2} \cdot p-6,{ }^{3} \cdot p-219-\right.$ 224]. At that time, the high-level administration was different from managing the industry level.

The term strategy was originally used as a military term, meaning the general's skill. The term strategic management was later used in business management in the first half of the 19th century [ ${ }^{4}$. p-17]. In countries with a transition to market economy, management, strategic management methods have been widely used in all non-entrepreneurial organizations, even in Muzaffar Abdurakhimov 
public administration[ ${ }^{5}$. pp-229-235]. Strategic management terminology has been given a number of scientific definition by some scientists as Peter Druker said, "Strategic management is not the sum of these guidelines. Scientel and Hatten say that "the process of identifying and establishing a connection with the surrounding environment," Higgens stated that "This is the process of managing the organization through its organization of its interaction with the environment", Pierce and Robinson said "A set of decisions and actions to formulate and implement strategies for organizational goals," as well as Joel Ross and Michael stated "Without a strategy, it's like a ship without a helm" [6].

According to Uzbek management scientists M. Sharifhodjaev and YO.Abdullayev stated that the strategic management is a long-term management style that combines the organization's future goals and capabilities with employees[7. pp.- 400-405 ].

Thus, strategic management can be characterized as a flexible management style, taking into account the organization's effect on the environment and the environment.

It was possible to see elements of strategic management at all stages of the management assessment [ ${ }^{8}$. pp.-11]. However, in the late 1970 s and early 1980s, strategic management was formed as a separate division of management.

Because of the development of science and the development of market relations, approaches on governance have improved. However, these approaches have served as the basis of past scientific approaches and experiments.

In 1992, David Osborne and Ted Gebler created a scientific work called "How to reorganize management: how entrepreneurial spirit transforms the public sector?" and thus founded a new school of government [ $\left.{ }^{9}\right]$. This school is called New Public Management, called "New Public Administration". Today's founders have introduced new and modern approaches to government management. This is quite different from the previous one. This difference reflects in ten principles of good governance of the state, developed by scientists. These are:

Ensuring economic efficiency of the public administration body; 2 . Ensure competition between government agencies and private enterprises in providing public services; 3. Privatization of unprofitable state-owned enterprises, reduction of state participation in the economy; 4 . Decentralization of central government on vertical lines on the principle of 
subsidy; 5. Implementing socially significant projects based on public and private partnerships; 6 . Separation of public policy and state administration; 7. Implementation of modern methods of management, financial management, regional marketing, planning and forecasting, project management, decision-making methods in public administration; 8 . Widespread use of outsourcing and outsourcing techniques in the use of public services; 9. Awareness of Public administration in order to improve information exchange between public authorities and the private sector; 10 . Loss of budget deficit (without increasing government debt, abandoning subsidies and subsidies and implementing privatization).

New public management theory focuses on results. Those outputs need to be monitored for the success of an organization. This organization needs to perform in order to achieve great results and to prove to be efficient. We will study the behavior of the agents inside an organization when they need to come up with a public policy, efficient for the problem that was brought in the agenda. This policy needs to be evaluated in order to see the impact that has on the environment to which it refers [ $\left.{ }^{10}\right]$.

Since this theory had shortcomings in the concept of the New Public Administration, P. Dunleavy and C. Hood generalized critical ideas[11]. The critics of this group are mostly supporters of the "Strong State" and "Strong Society." Supporters of the "strong state" think that "New Public Management" mainly serves to increase the effectiveness of government services. At the same time, the bureaucratic management system is more effective in managing defense. Supporters of the "strong society" believe that the new public administration doctrine has not been given a mechanism to prevent corruption. In addition, there is a lack of in-depth knowledge of the mechanisms of public control over state management. In the opinion of social partners, because of the commercialization of public services, the priority of non-profit organizations is to achieve profitability and develop social entrepreneurship. In turn, they criticized the government for the weakening of their support[12].

Despite these shortcomings, the principles of "new public administration" are widely used in developed countries - the United States, the United Kingdom, and Australia. In these countries, the market economy is highly developed and public services are commercially viable and the share of the public sector is low.

The theory of public administration "Good governance". The concept of "Good Governance" was reflected in UNDP documents in 1997[13]. This Muzaffar Abdurakhimov 
education was then reflected in the documents of the World Bank[14], the International Monetary Fund[15] and the European Union[16]. The United Nations has formulated a modern concept of education in 2006. The key aspects of this Good Governance concept are that the ultimate goal is to have a high trust between the state and society. In addition, this doctrine is not only the usual provider of public services, but also as citizens, NGOs, business partners, as well as entrepreneurs, that is, government and society are jointly governed.

Therefore, in general, there are two "New Public Management" and "Good Governance" in modern state governance. Both proponents also recommend that they abandon the Strong State system based on administrative bureaucracy. Particularly, the first public supporters of New Public Management offered to reduce government involvement in the economy, introduce business management methods into the public administration system, implement public-private partnership mechanisms, introduce public sector outsourcing, and the second direction, Good Governance, and the transition to a stronger society through monitoring.

The approaches of the above-mentioned management schools show that management has initially been engaged in research, production, organization-level research. Management posters have been developed and developed at a nation-wide level of management, management, and management at a nation-wide level.

The conclusion is that the government has its own ancient history. At that time, he progressed and developed. All managerial methods and approaches had weaknesses along with their accomplishments. As the development of information telecommunications, globalization, increased competition in the market, a decline in production resources, and rapid change in the environment of organizations, the need for management science and effective management methods are becoming more urgent.

The term strategy was initially planned and implemented by the military, who planned and planned the few tactics and operations that had to be predicted by war. It can also be said that the term goes hand in hand with its managing attributes. It also means that methods and plans of navigation are adapted to the changes that are likely to occur when designing and implementing predictable situations.

Today, the global market conditions have changed dramatically, and in the age of globalization competition, the entire organization, using forms of ownership, uses modern methods of strategic management to ensure that Muzaffar Abdurakhimov 
they operate efficiently. Enterprises that provide public services also adapt to the conditions of the market economy, and proper watering of their activities with the business spirits will have a great impact on the reduction of budget expenditures and the quality of these services. 


\section{References}

1. L.E. Basovsky. Strategic management. Textbook. -M: Infra-M, 2012. p-365

2. David, Fred R. Strategic management: concepts and cases / Fred R. David. - 13th ed. p. cm. ISBN-13: 978-0-13-612098-8 (case bound) ISBN-10: 0-13-612098-9 (case bound) 2011.

3. Bracker, J. 1980. The historical development of the strategic management concept. Academy of Management Review, 5(2), 219-224.

4. Neil Ritson. Strategic Management \&Ventus publishing ApS. ISBN 978-87-7681-417-5. 2011.

5. David Osborne and Ted Garbler. 1992. Reinventing Government: How the Entrepreneurial Spirit Is Transforming the Public Sector. Reading, MA: Addison-Wesley. / Janet A. Weiss The Academy of Management Review Vol. 20, No. 1 (Jan., 1995), pp. 229-235 http://www.jstor.org/stable/258896?seq=1\#page_scan_tab_contents

6. Strategic management: a textbook for universities / sub-editor. A. N. Petrova. - St. Petersburg. : Peter, 2005. - p-496.

7. Higgins J.M. Organizational Policy and Strategic Management: text and Cases. 4nded. Chicago, The Drydent Press, 1983

8. Pearce J.A., Robinson R.B. Jr. Strategic Management. 2nded. Homewood, III, Richard D. Irwin, 1985

9. A. A. Thompson-junior. A. J. Strickland III. Strategic Management. M: 2012. p- 922.

10. A.Matei, C.Antonie. The New Public Management within the Complexity Model, Procedia - Social and Behavioral Sciences, Volume 109, March 2014,

pp.-1125-1029, https://www.sciencedirect.com/science/article/pii/S1877042813052385

11. M. Sharifkhadjaev. Y. Abdullaev. Management: Textbook. Tashkent, "Teacher", 2001 p-704.

12. L.E. Basovsky. Strategic management. Textbook. -M: Infra-M, 2012. p-365

13. David Osborne and Ted Gaebler. 1992. Reinventing Government: How the Entrepreneurial Spirit Is Transforming the Public Sector. Reading, MA: Addison-Wesley. Janet A. Weiss the Academy of Management Review Vol. 20, No. 1 (Jan. 1995), pp.-229-235/ http://www.jstor.org/stable/258896?seq=1\#page_scan_tab_contents.

14. Dunleavy P., Hood, C. (1994). From old Public Administration to New Public Management. Public Money\& Management, 14(3), 9-16.

Muzaffar Abdurakhimov 
15. Aikenberry A. M., Drupal Kluwer, J.(2004). The Marketization of the Nonprofit Sector: Civil Society at Risk? Public Administration Review, 64(2), pp-132-140.

16. Governance for Sustainable human Development. New York: UNDP,1997

17. Kaufmann, Daniel, Cray, Aart and Mastruzzi, Massimo, the Worldwide Governance Indicators: Methodology and Analytical Issues (September 2010). World Bank Policy Research Working Paper №. 5430.

18. The IMFs Approach to Promoting Good Governance and Combating Corruption - A guide International Monetary Fund. 2005.

19. European Governance. A White Paper. Commission of the European Communities, 2001. 